\title{
(SELECTED PRESENTATIONS)
}

\section{ÇOCUKLUK ÇAĞINDA KRONIK HEPATIT B ENFEKSIYONUNUN KLINIK ÖZELLIKLERI VE UZUN DÖNEMLi IZLEM SONUÇLARI. RUTIN AŞILAMA PROGRAMI SONRASI NELER DEĞişTi?}

\author{
Sebahat Çam \\ istanbul Medeniyet Üniversitesi Çocuk Sağlığı ve Hastalıkları AD, Çocuk Gastroenteroloji BD, \\ istanbul, Türkiye
}

\begin{abstract}
Amaç: Kronik Hepatit B (HBV) enfeksiyonu sessiz seyredebileceği gibi kronik hepatitten siroza hatta hepatosellüler karsinoma kadar yol açabildiği klinik tablolar nedeniyle önemli bir halk sağlığı sorunu oluşturmaktadır. Hepatit B aşısı 1998 yılında ulusal aşı takvimine alınmıştır. Çalışmamızda Çocuk Sağlığı ve Hastalıkları kliniğine başvuranhastalarda kronik hepatit B sıklığını saptamak, risk faktörlerini belirlemekhastaların klinik özellikleri, uzun dönemli izlem sonuçlarını değerlendirerek, aşılama programı öncesi ve sonrası hasta sayısı ve karakterindeki değişiklikleri belirlemek amaçlanmıştır.
\end{abstract}

Yöntem: 2006-2018 yılları arasında Göztepe EAH Çocuk Sağlığı ve Hastalıkları Kliniğine başvuran 0-18 yaş arası (ortalama 93 ay) 381 hasta (236 erkek, 145 kız) çalışmaya alındı. 1998 ve sonrası doğumlular (150 olgu) bir grup, 1997 ve öncesi doğumlular (231 olgu) bir grup olarak ayrıldı. Hastaların başvuru yakınmaları, aile öyküleri, risk faktörleri, $\mathrm{HBeAg}$ durumları, ek hastalıkları, tedaviler ve uzun dönemli takipleri hasta kayıt ve dosyalarından retrospektif olarak değerlendirildi.

Bulgular: 2006-2010 yılları arasında çocuk polikliniğine başvuran hasta sayısı 321 iken, 2011-2018 yılları arasında başvuran hasta sayısı 60 idi.87 hastada annede, 26 hastada babada, 34 hastada kardeşte, 19 hastada diğer aile bireylerinde HBV enfeksiyonu saptanması nedeniyle yapılan aile taramasında hepatit B enfeksiyonu saptanmışt. 19 olguda annede gebelikte yapılan serolojik testlerde hepatit $B$ enfeksiyonu varlığı saptanmış, 42 hastada ise annenin 2. veya 3. gebeliklerinde HBV serolojisi pozitif bulunması nedeniyle önceki çocuklarında HBV(+) bulunmuştur. Bu olgularda anneye önceki gebeliklerinde tarama yapılmadığı ve annenin durumundan habersiz olduğu ifade edilmiştir. 49 olguda rutin sağlık taraması, aşı yapılması öncesi okul, havuz, staj başlama öncesi bakılan testlerde, 69 hastada halsizlik, karın ağrısı, bulant vb non spesifik yakınmalar nedeniyle, 22 hastada elektif operasyon öncesinde, 12 hastada malinite nedeniye tedavi öncesi ve izlem sırasında ve 3 hastada diğer nedenlerle yapılan testlerde hepatit B taşıyıcılı̆̆ı saptanmıştır. 1998 ve sonrası doğumluların hepsinde annede taşıyıcılık mevcuttu. Hastalardan 63 tanesi interferon ve antiviral tedavi aldı. 29 olguda anti Hbe pozitifliği gelişti. Tedavisiz izlenen hastaların 22 sinde spontan antiHbe(+) leşti. Hepatik yetmezlik gelişen hasta olmadı.

Sonuç: Çalışmamızda Kronik HBV sıklığının aşılama programı sonrasında oldukça azaldığı izlenmektedir.1998 sonrası doğumluların tamamında annede taşıyıcılık olması aşılama ile çocuklarda vertikal geçişli olanlar dışındaki enfeksiyonların kontrol altına alındığını, daha çok kronikleştiği bilinen antenatal ve natal geçişli Hepatit $\mathrm{B}$ enfeksiyonlarının gebelikte tarama ile saptanması, gebelikte uygun tedavi ve bebek doğar doğmaz aşı ve Ig tedavisi verilmesi gerektiğinin önemini vurgulamaktadır. Tarama ile yakalanan hastaların fazlalığı da indeks vakaların yakınlarının taranmasının önemini bir kez daha göz önüne sermektedir.

Address for Correspondence: Dr. Sebahat ÇAM, İstanbul Medeniyet Üniversitesi, Çocuk Sağlığı ve Hastalıkları Anabilim Dalı, Çocuk Gastroenteroloji Bilim Dalı, İstanbul-Türkiye E-mail: imamoglus@yahoo.com 